Proc. Estonian Acad. Sci. Eng., 2003, 9, 3, 185-208

\title{
Geological setting of areas endangered by waves generated by fast ferries in Tallinn Bay
}

\author{
Jüri Kask $^{\mathrm{a}}$, Aado Talpas ${ }^{\mathrm{b}}$, Andres Kask ${ }^{\mathrm{a}}$, and Klaus Schwarzer ${ }^{\mathrm{c}}$ \\ a Marine Systems Institute, Tallinn Technical University, Akadeemia tee 21, 12618 Tallinn, Estonia; \\ jyri.kask@phys.sea.ee \\ b Geological Survey of Estonia, Kadaka tee 82, 12618 Tallinn, Estonia \\ c Institute of Geosciences, Christian-Albrechts-University of Kiel, Ohlshausen Strasse 40, 24118 Kiel, \\ Germany; kls@gpi.uni-kiel.de
}

Received 14 April 2003, in revised form 19 June 2003

\begin{abstract}
The paper considers the distribution of bottom deposits in Tallinn Bay in connection with the general geological setting. The shores subject to intense ship wash (western coast of the Viimsi Peninsula, SW coast of Aegna Island, and eastern coast of Naissaar Island) are discussed in greater detail. Distribution of bottom deposits is determined by the location of erosion areas and seafloor topography. The shores of the bay are mostly covered with coarse material washed out from glacial deposits, which reduces the influence of the waves. During the periods with low water level the waves generated by fast ferries influence deeper parts of the nearshore.
\end{abstract}

Key words: Tallinn Bay, fast ferries, shore, bottom deposits.

\section{INTRODUCTION}

The aim of the study was to obtain background information about the geological setting of the areas endangered by waves generated by fast ferries in Tallinn Bay. To interpret the hydrodynamical processes on the seafloor and along the coastline we must know the relief of these areas. Waves influence the seafloor when the water depth is less than half of the wavelength $\left[{ }^{1}\right]$. As the highest components of the waves generated by fast ferries are much longer than those of wind waves during even severe storms $\left[{ }^{2}\right]$, they influence also deeper zones of the nearshore. The dominating period of the waves generated by fast ferries is at least twice longer than the typical period of wind waves.

Depending on the geological setting of the seafloor, either erosion, sediment transport, or deposition of sediments occur. If waves are accompanied by 
currents, eroded material can be transported over long distances (for several kilometres).

Wind waves as well as waves generated by fast ferries play an important role in sediment distribution and erosion of the seafloor and shores in Tallinn Bay. Sediment distribution on the seafloor is determined by the geological prerequisites, by the intensity and direction of waves and currents, by short-period and long-lasting sea level changes $\left[{ }^{3}\right]$, and ice conditions. The influence of wind waves is most intensive during the autumn-winter period when the sea level is high, but the influence of waves generated by fast ferries is most intensive during the lower sea level in summer.

Since the waves generated by fast ferries frequently have a much longer period than wind waves, ship waves can influence the seafloor to the depth of $20 \mathrm{~m}$. Several studies $\left[^{4-6}\right]$ have predicted or described the destruction of shores as well as the seafloor owing to fast ferries' wakes. In recent years the fast ferry traffic in Tallinn Bay has greatly intensified. It is considered as a possible reason for coastal destruction in several areas around Tallinn Bay (SW coast of Aegna Island, eastern coast of Naissaar Island and western coast of the Viimsi Peninsula; see map of Tallinn Bay on the inside back cover of this issue). In order to study this assumption more profoundly, in 2001 respective investigations were initiated $\left[{ }^{7}\right]$, financed by the Estonian Environmental Investment Centre. The studies also included detailed investigations of the bathymetry, geological setting, and structure of bottom sediments in the above-mentioned endangered areas. The results allow to identify the influence of the water movement on seafloor erosion, sediment transport, and accumulation, to forecast the influence of waves of different origin and, if needed, to estimate the maximum permissible anthropogenic wave load in vulnerable shore sections.

\section{MATERIAL AND METHODS}

The description of the geological setting and the bottom deposits in Tallinn Bay is based on the geological mapping at 1:200000, carried out by the Geological Survey of Estonia $\left[^{8}\right]$.

In the framework of the present study, geological investigations were performed in three areas: western coast of the Viimsi Peninsula, SW coast of Aegna, and eastern coast of Naissaar. Within the above areas detailed investigations were carried out on smaller sites, characteristic of the area, where, based on pilot measurements $\left[{ }^{7}\right]$, high ship wave load was expected and which are potentially vulnerable to increased wave load.

On the Viimsi Peninsula the observed shore section reaches from Merivälja to Rohuneeme harbour (about $10 \mathrm{~km}$ ). On Aegna detailed investigations were carried out northward of the Talneem Cape (length about $500 \mathrm{~m}$ ), where an about $2 \mathrm{~km}$ long eroded section was observed. On Naissaar an about $7 \mathrm{~km}$ long section on its eastern coast was studied. Detailed investigations were performed north of the 
harbour (about $450 \mathrm{~m}$ ) and north of the Hülkari Cape (about $500 \mathrm{~m}$ ). Geological investigations were carried out from August to October, 2001.

First of all, the beaches exposed to ship wakes, were observed and the erosion and accumulation processes were generally estimated. Sections, where considerable changes had occurred, were photographed and mapped. This work served as the basis for determining the beaches influenced by the waves generated by fast ferries.

The following seafloor investigations were carried out: bathymetric surveying and seafloor topography; mapping of the distribution of bottom deposits and their composition; diving to describe in detail the character of the seafloor; drilling to determine the thickness and properties of the Quaternary deposits; geophysical surveying; laboratory studies.

Two cruises of research vessels Mare and Littorina were organized, during which the seafloor and the nearshore area were investigated mainly by geophysical methods, sampling also bottom deposits. From Mare the sea area around Aegna and Naissaar was investigated by boomer system EG\&G, LC-100 (width of the studied strip $200 \mathrm{~m}$ ). From Littorina more detailed investigations of the seafloor topography were carried out using a Klein 595 sidescan sonar system and a boomer system (in the total of about $60 \mathrm{nmi}$ ). They gave a review of the geological setting of the seafloor eastward of Naissaar. The operating frequency of the seismoacoustic station was 500-1500 Hz.

The bathymetric surveying and topographic investigations of the seafloor were carried out using echo sounder-sonar Interphase PC/180 and echo sounder PEL-3. The latter recorded the seafloor topography on a paper tape. Investigation points of the echo sounder survey were located by navigator Garmin12XL with a differential block, using GPS (DGPS) corrections from the Porkkala differential GPS station. Investigations were carried out from a rubber boat (length $6 \mathrm{~m}$, width $2 \mathrm{~m}$ ). Bottom deposits were sampled by a grip scoop and a corer, specially designed for sampling of soft deposits.

In the areas of detailed investigations, the surveying of the seafloor topography and mapping of bottom deposits were carried out. The bottom deposits were sampled and grain-size analyses were performed to determine the distribution of different types of bottom deposits as well as their possible transport by waves and currents. In the Aegna investigation area, 13 temporary pickets were installed in order to register the changes in the shore scarp. In the observation area of the Viimsi Peninsula, drillholes were made by the drilling rig UGB-1VS of the Geological Survey of Estonia. The Quaternary sequence of the drillcores were described in situ. The coastal zone of all investigation areas (and in places outside these) was investigated also by diving. Grain-size composition of the bottom deposits was determined by sieve analysis.

The influence of storms on the studied shore sections was visually assessed directly after a severe storm on 15 November 2001. On the Viimsi Peninsula and Aegna (where the coastal monitoring areas, established within the state 
environmental monitoring programme, are located) the changes in the abrasion scarp were measured.

Repeated observations were carried out in all investigation areas from March to October 2002, mainly by diving and bathymetric surveying. During diving, the changes in the pattern of bottom sediment distribution were registered. Photos and videos were made to improve the detection of the changes.

\section{SEDIMENT TRANSPORT IN THE COASTAL ZONE}

The size of the particles basically controls the sediment transport and distribution. Sand (grain size $0.063-2 \mathrm{~mm}$ ) prevails in the coastal zone of the areas under observation. Finer sediments are represented by pelite and their properties are strongly influenced by electrochemical and biological cohesion. The effect of cohesion is important in determining the sediment properties if more than $10 \%$ of the sediment consists of grains smaller than $0.063 \mathrm{~mm}$. Such mixtures are more resistant to erosion than, for example, pure sand $\left[{ }^{9}\right]$. Grains larger than $2 \mathrm{~mm}$ are classified as gravel. The permeability of gravel is an important factor determining its behaviour, and the proportion of sand mixed with the gravel can reduce its permeability.

Seafloor sediments can be moved by currents or waves, or very commonly by both acting together. Sediments are carried due to the basic processes of entrainment, transportation, and deposition, which occur simultaneously and may interact with each other. Entrainment takes place as a result of the friction exerted on the seafloor by the currents and/or waves, with turbulent diffusion possibly forcing the grains into suspension $\left[{ }^{9}\right]$.

Current- or wave-induced transportation occurs by rolling, hopping, and sliding of grains along the bed. This is known as bedload transport and it is the dominant mode of transport for slow flows and/or large grains [ $\left.{ }^{9}\right]$. If the flow is fast or the waves large enough and the grains fine enough, sand will be forced into suspension up to a height of several metres above the seafloor and transported by currents. Such transport mode is known as suspended load and it often considerably exceeds the bedload transport. The transport of the bottom deposits often occurs as bedload transport for grains coarser than $2 \mathrm{~mm}$, and as suspended load for grains finer than $0.2 \mathrm{~mm}\left[{ }^{9}\right]$.

The rate of net accretion or erosion of an area of the seafloor depends on the difference in the rates at which sand is entering and leaving the area. If the amount of sand carried into a region is bigger than the amount carried simultaneously away, then accretion of the bed takes place; if the opposite is true, then it erodes. Even if the sediment transport rate is very high, the seafloor level will not change if the input balances the output.

The threshold of motion of sediments on the seafloor is an important factor in most computations concerned with the response of the sediments to currents and waves. For very slow flows over a sandy seafloor, the sand remains immobile. If the flow velocity increases, a velocity is reached which forces a few grains into 
movement. This is called the threshold (or initiation) of the motion $\left[{ }^{9}\right]$. A similar process occurs beneath waves and owning to the joint influence of waves and currents.

If different silt fractions (fine and coarse) are transported at a certain flow rate, then a stronger flow is needed to bring finer particles into motion $\left[{ }^{10}\right]$. This can be explained by the cohesion of the particles. The threshold of sand mobility depends on the amplitude of bottom orbital velocity (thus on both the wave height and period), and the grain diameter and density [ $\left.{ }^{9}\right]$.

The mechanical influence of waves on sediments and rocks is mainly connected with surge flows. Water masses, bearing abundant sediment particles and moving at a high rate can cause considerable erosion. As the result of the hydrodynamic activity, a flat or gently sloping beach may form. In some places a pavement composed of the coarse material, washed out from till, is created.

Bedload is the dominant transport mode for low flow rates and large grains. Coarse sand and gravel are transported mostly as bedload. For stronger flows, exceeding the threshold of suspension, bedload transport still occurs, but the amount of sand carried in suspension will often be very much greater than that carried as bedload, especially for fine sands.

In the presence of waves, the net bedload transport is zero if the oscillatory velocity is symmetrical (for example, sinusoidal). However, the transport of the sediment during half of a wave cycle is of interest in some applications. In asymmetric wave motions, which occur under steep waves in shallow water, there is a non-zero net sediment transport because transport beneath the wave crest is higher than the transport beneath the trough, resulting in a net sediment transport in the direction of wave propagation. The net transport can then be calculated as the difference between the half-cycle transport beneath the crest and the half-cycle transport beneath the trough [ $\left.{ }^{9}\right]$.

Deposition occurs when grains come to rest in the bedload transport, or by settling out of suspension. Most of the time, entrainment of some grains upward into suspension and settling of other grains downward due to their weight take place simultaneously.

Waves can carry sediment material in different ways $\left[{ }^{9,11}\right]$. Currents and turbulence raise the suspended sediment particles above seafloor and carry it forward. When waves break, longshore currents are formed, which also carry sediments. In the case of fast ferry waves, formation of such currents is unlikely since the duration of wave packages (some minutes) $\left.{ }^{2}\right]$ is too short $\left[{ }^{5}\right]$. Orbital velocity of water movement under the wave crest is higher than under the wave bottom. Consequently, more sediments are transported under the wave crest. As a result of the described processes, sediment material is normally transported in the direction of wave travelling (generally towards the shore).

Sediment transport by the waves generated by fast ferries is probably more intense than by wind waves, since the profile of ship waves is often strongly asymmetric $\left[{ }^{5,12}\right]$. Thus sediment transport by fast ferry waves generally occurs perpendicular to the shoreline $\left[^{5}\right]$. Due to their length, fast ferry waves often break 
relatively far from the shoreline, therefore they influence fine sediments more intensely in the deeper part of the nearshore $\left[{ }^{13}\right]$. This feature may cause considerable changes in the sediment distribution. During the period when fast ferry traffic occurs, frequently low water level dominates, therefore the waves induced by ferries affect even deeper parts of the seafloor.

\section{GEOLOGICAL SETTING OF THE TALLINN BAY AREA}

Different stratigraphic units crop up on the seafloor of Tallinn Bay. Cambrian sandstone appears sporadically in small areas, for example, in the surroundings of the Paljassaare Peninsula, on the nearshore west of the Viimsi Peninsula and Aegna, and on the Tallinn Bank. This unit is usually overlain by a thin layer of sand and silt; the latter is carried away by strong waves.

Contemporary sedimentation areas in Tallinn Bay have been formed under the influence of several agents: general circulation, currents generated by local winds, wind waves, and the sea floor topography.

The Pleistocene till and late- and postglacial clays are rather common. Lateand postglacial clays crop out in the areas where sediment transport takes place (western coast of the Viimsi Peninsula, underwater extension of the Kopli Peninsula, the Kopli Bay, SE and SW of Naissaar, see figure on the inside back cover). Postglacial clays are spread on the western slope of a deep linear depression in the central part of Tallinn Bay. Due to hydrodynamical conditions, for a long time neither considerable deposition nor erosion has occurred in the above-mentioned areas. In some places a thin (less than $10 \mathrm{~cm}$ ) layer of sand or gravel of unidentified origin, or Fe-Mn nodules of various shape and size, are present.

Residual sediments (coarse fractions left after fine fractions have been carried away) of variable grain size (boulders to silt) form an independent sediment type. They overlie the bedrock or till and have formed mainly as the result of wave activity. Finer particles are carried away to the deeper sea, while coarse material remains in the zone of wave activity, thus forming a pavement on the seafloor. Such areas occur around Aegna, as well as in the coastal zone of the Kopli and Paljassaare peninsulas. The pebble and boulder pavement with some sand fill is common on the western coast of the Viimsi Peninsula and on the eastern coast of Naissaar, where it covers almost the whole coastal zone to a depth of 5-6 m. Sparse boulders occur, sometimes covered by water, but in some places they are partly exposed above the sea level. Presently in the areas covered with residual deposits, erosion and sediment transport take place, serving as a source of sediments deposited within Tallinn Bay.

In the shallow coastal areas, which are subject to wave wash, erosion plays an important role. As the result of wave breaking, coarse, poorly sorted sand, seldom also gravel and pebbles may accumulate at the shoreline. In more than $10 \mathrm{~m}$ deep areas the finely bedded or non-bedded silts accumulate. 
In the central part of Tallinn Bay, varigrained sand accumulates, which originates from the eroded shore sections at the ends of the peninsulas. The varigrained sand southward and SW of the islands and banks has accumulated similarly. The formation of areas covered with such deposits is controlled by prevailing winds, blowing from WSW and $(\mathrm{N}) \mathrm{NW}\left[{ }^{14}\right]$. Such accumulation areas are, for example, the surroundings of the Hülkari Cape on Naissaar. Both, the cape and the seafloor south of the cape consist of sand, which has been carried to this area from the eroded shores of Naissaar. Fine and medium sand are widely distributed in Tallinn Bay and coarse sand is found in shallow areas.

Fine deep-water (over $20 \mathrm{~m}$ ) sediments are represented by pelitic material, which sporadically contains organic matter. Greenish grey to black pelite with high water content are found in seafloor depressions. The share of particles finer than $0.01 \mathrm{~mm}$ is about $70-80 \%$, the silt fraction (less than $0.063 \mathrm{~mm}$ ) is the main admixture. Generally darker (to black) pelite occurs in deeper areas (30-40 m), while a greenish variety is found in somewhat shallower areas. Such deposits are found in small areas only - west of Aegna (maximum thickness of pelites is $6 \mathrm{~m}$ ). To the south of this area the seafloor is covered with silt, with a thickness up to 5-6 m. SW of Aegna and Kräsuli (a small island between Aegna and the Viimsi Peninsula) the thickness of modern bottom deposits is only $0.20-0.30 \mathrm{~m}$. This is apparently due to westerly-easterly current dominating in the southern Gulf of Finland, which turns to NE near the Paljassaare Peninsula and partly passes the straits between Aegna and the Viimsi Peninsula.

Eastward of the Paljassaare Peninsula nearshore sediment transport is not observed and silt and pelite are deposited in a relatively shallow water. A similar situation is observed in the Kopli Bay, where sand accumulates in the eastern part of the bayhead, while in the western bayhead wave activity is less intense and silty and pelitic material is deposited.

\section{GEOLOGICAL SETTING OF THE COASTAL ZONE INFLUENCED BY SHIP WAVES}

A review of the geological setting of the coastal zone enables us to identify whether there are connections between ship wakes and erosion and accumulation processes besides geological prerequisites. The bedding conditions of sediments determine the formation of the seafloor topography, and this in turn influences currents and wave activity. The contemporary marine sediments of the coastal zone are subject to intense wave wash and their transport is closely connected with wave activity.

\subsection{Western coast of the Viimsi Peninsula}

The coastal processes on the western coast of the Viimsi Peninsula were investigated in the area northward of Pirita beach (see figure on the inside back 
cover). Numerous boulders, both below and above the water level, occur in the shallow nearshore.

In the neighbourhood of Pringi and Rummu villages, banks, boulders and cobbles are observed on the nearshore (Fig. $1^{*}$ ). Northwest of Rohuneeme harbour there is an extensive shallow sea area, with boulders and cobbles.

The geological setting of the shore as well as of the nearshore is complex. On land, the beach ridge systems alternate with exposures of till and Cambrian blue clay. Near Miiduranna harbour the coastal zone is made of loam and sandy loam till (Figs. 2 and 3).

On the shore the till is overlain by a thin layer of sand. The upper surface of the till bed is inclined towards the sea and on the nearshore the till is covered with varved clay and marine sediments. The thickness of contemporary sediments (sand and silt) is small, which indicates that active sedimentation does not take place here.

North of the Miiduranna area till is spread to the end of the peninsula and is covered by a thin layer of younger deposits. In several places in the coastal zone there is a pavement of pebbles and cobbles, protecting the sea floor from erosion. Near Pringi and Püünsi villages the thickness of till in the coastal zone decreases and in the northernmost part of the Viimsi Peninsula only $0.10-0.50 \mathrm{~m}$ of till covers the Cambrian blue clay.

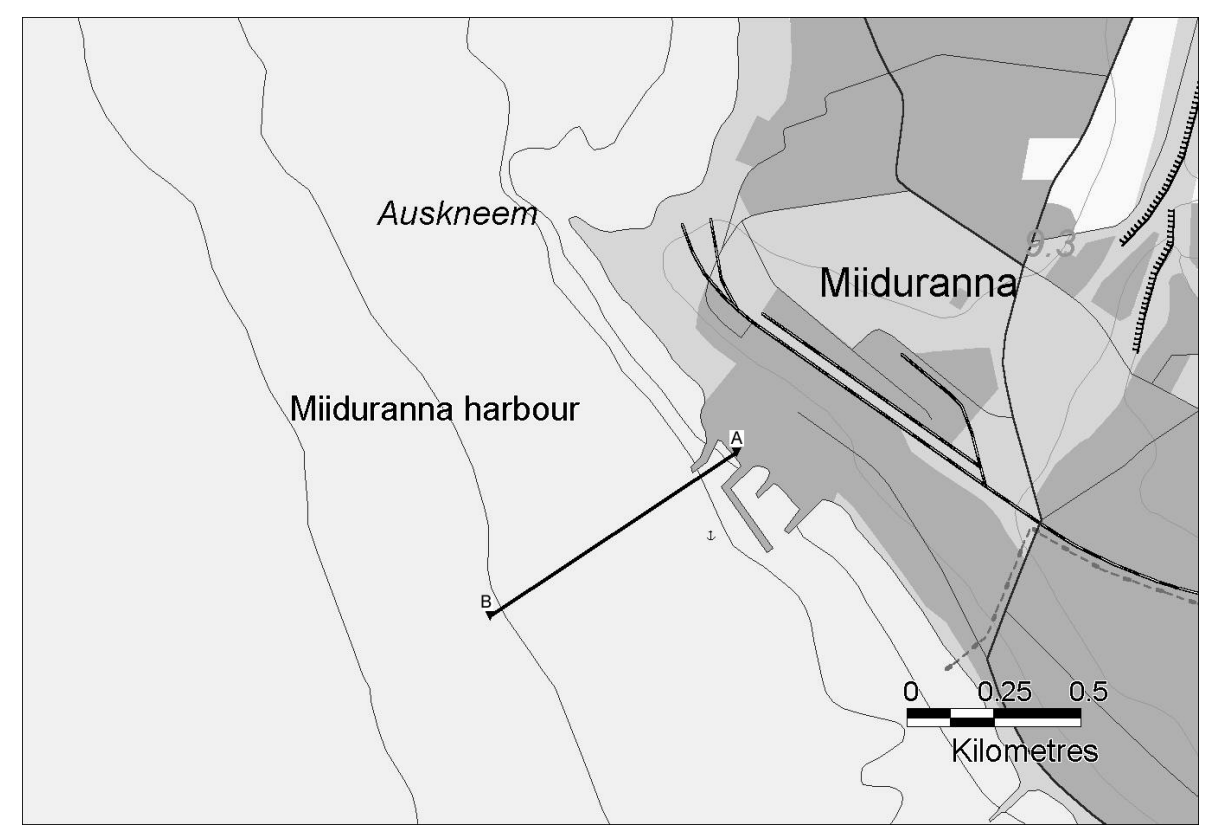

Fig. 2. Location of the geological cross-section at Miiduranna harbour (topographic base - the base map of Estonia at the scale of $1: 50000$ ).

\footnotetext{
${ }^{*}$ Asterisks mark coloured figures.
} 


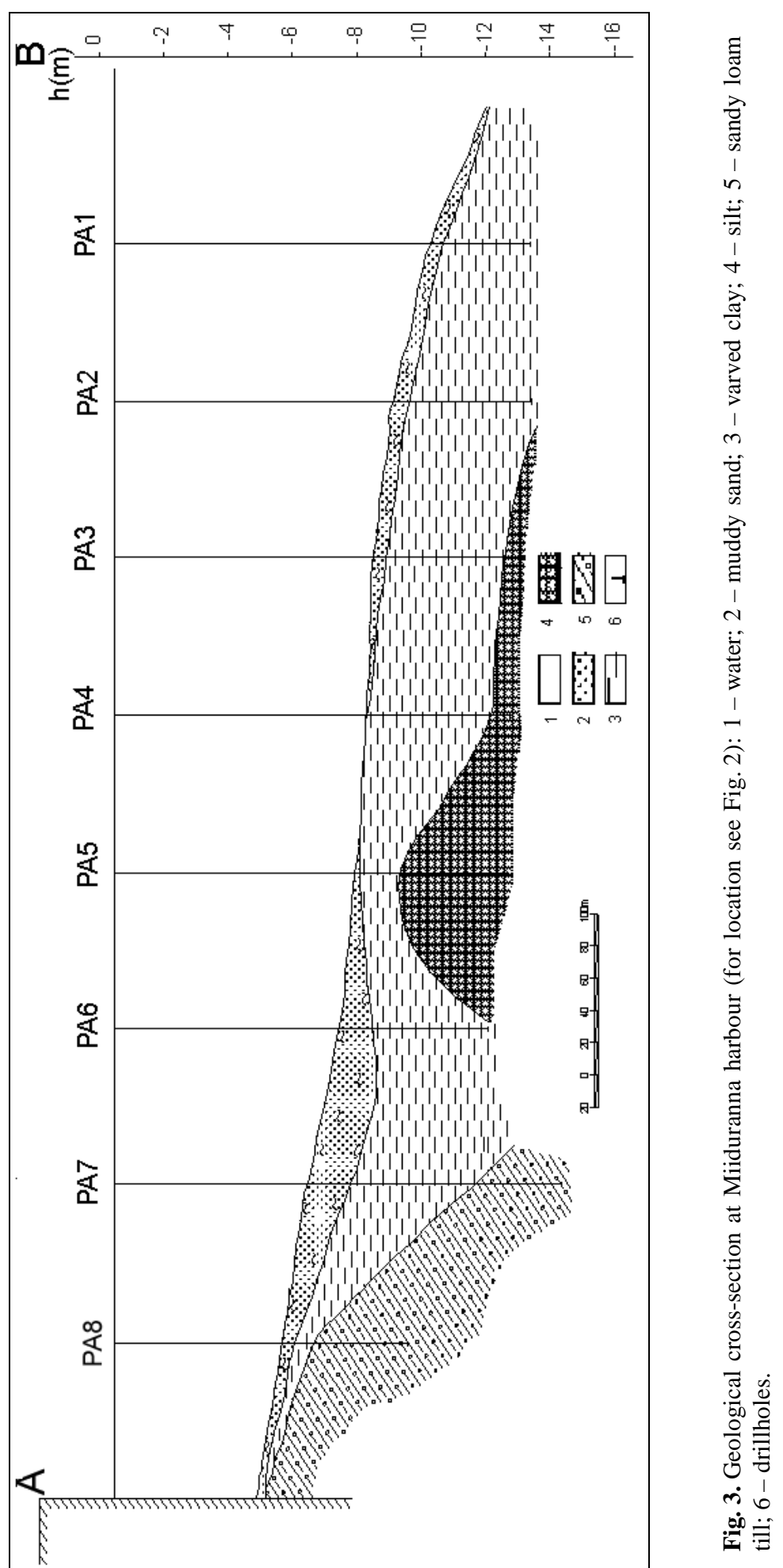


The distribution pattern of bottom sediments in the shallow sea near the western coast of the Viimsi Peninsula is related to the depth of the water. In the zone closest to the shoreline, erosion takes place and sandy sediments have been carried away. The seafloor is covered by a pebble and cobble pavement, sometimes gravel is found as well. Seaward of the erosion zone there is a zone of transportation, where sand and gravel occur, forming ripples in places. Further seaward the seafloor is covered by pebbles and cobbles, which in turn borders the area permanently covered by bottom deposits (mostly sand and silt).

Coastal destruction may occur under conditions of high water level and intense wave action (during severe storms). Sometimes a low scarp is formed in loose sediments, while in other places sediments are accumulated on the shore. However, fine sediments are usually carried away to deeper sea.

The waves generated by fast ferries usually have a height of $0.50-0.80 \mathrm{~m}$ when they reach the shore. Depending on the wave length, in certain shore sections the wave wash considerably influences the sediment transport.

Intense wave activity may cause changes in sediment distribution, but when the conditions normalize, the usual distribution pattern is restored in about $0.5-1$ year. On 15 November 2001, during a severe storm, the water level in Tallinn Bay rose about $130 \mathrm{~cm}$ above the average and the accompanying intense wave wash eroded parts of the shore that normally were not subject to erosion. Thus a large amount of sediment material was released and distributed on the shore and nearshore. Near Pringi village, the zone closest to the shoreline is normally covered by a pebble and cobble pavement with few boulders, but after the abovementioned severe storm there was also a lot of sand.

The adjacent seaward zone, which is rather narrow and where sediment transport obviously occurs, consists of medium sand. After the storm, the pavement covering the till was exposed and sand was present only sporadically. More seaward a zone of pebbles and cobbles follows, but the pavement alternates with gravel and sand. In the deepest zone the seafloor is covered by fine sand and silt, intense sediment accumulation is not observed.

The distribution of bottom sediments in the observed area (fine fractions such as silt and pelite are not found on the nearshore) indicates that sedimentation processes are strongly influenced by wave activity.

The storm in November 2001 caused changes in all zones described above. The results of diving, performed in 2001 and 2002, show that in summer 2002 the primary sediment distribution pattern (like in summer 2001) was restored. During the summer period the changes in the sediment distribution were insignificant.

\subsection{Southwestern coast of Aegna}

The geological setting of this area is simple (Figs. 4 and 5): on the shore and in the nearshore area the bedrock is covered by till of the last glaciation, and upon this a thin layer of contemporary marine sediments is found. Further landward the upper part of the Quaternary cover is composed of sand and in 


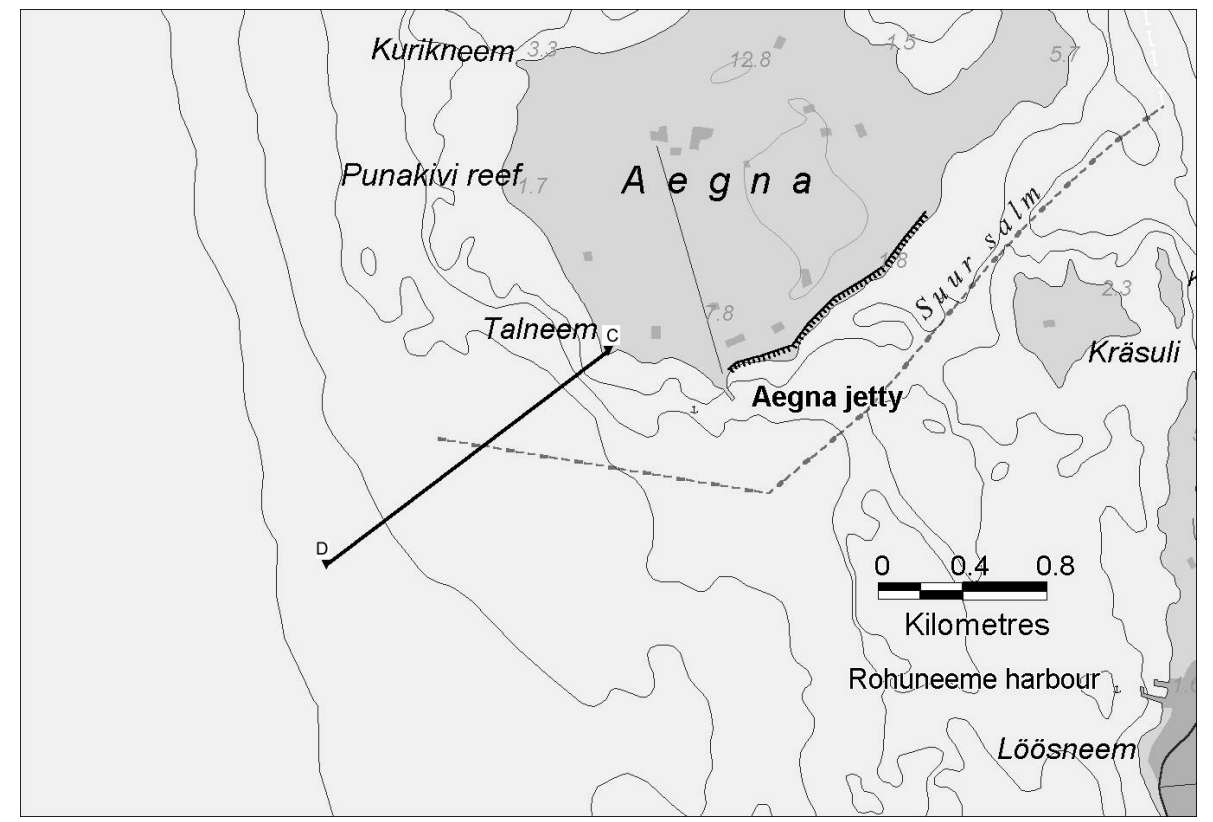

Fig. 4. Location of the geological cross-section on the SW coast of Aegna (topographic base - the base map of Estonia at the scale of 1:50 000).

places dunes occur. Finer sediments have been carried away from the coastal zone made of till, and a pebble and boulder pavement has formed (Fig. 6*). From the Talneem Cape to the Punakivi Bank the depth increases abruptly and the breaker zone is close to the shoreline. North of the Punakivi Bank to Kurikneem Cape the depth increases gently and the influence of wave wash on the sea floor decreases.

The seafloor of the nearshore area (water depth 6-10 m) is covered with pebbles and cobbles, with some gravel and sand. This pavement covers loam till. At a depth of 10-12 $\mathrm{m}$ coarse sand is found sporadically, with ripples on its surface. The ripples indicate that in this zone wave wash affects the sea floor. Unfortunately, there is no information whether the ripples were present before the beginning of the fast ferry traffic. At the depth of 12-14 m fine sand and silt are sporadically found on the seafloor.

The bottom deposits around the Talneem Cape have been formed under intense wave wash conditions. In the zone closest to the shoreline the seafloor is covered with pebbles, cobbles and boulders, in some places sand and gravel are found between them. The pavement protects the floor from further erosion. Further seaward the pavement alternates with areas where sand and gravel occur and further offshore coarse sand and gravel with few pebbles are spread. In the deepest zone the bottom deposits consist of fine sand and silt. In these three zones sediment transport occurs and finer deposits (from silt to gravel) are apparently carried with currents to sedimentation areas. 


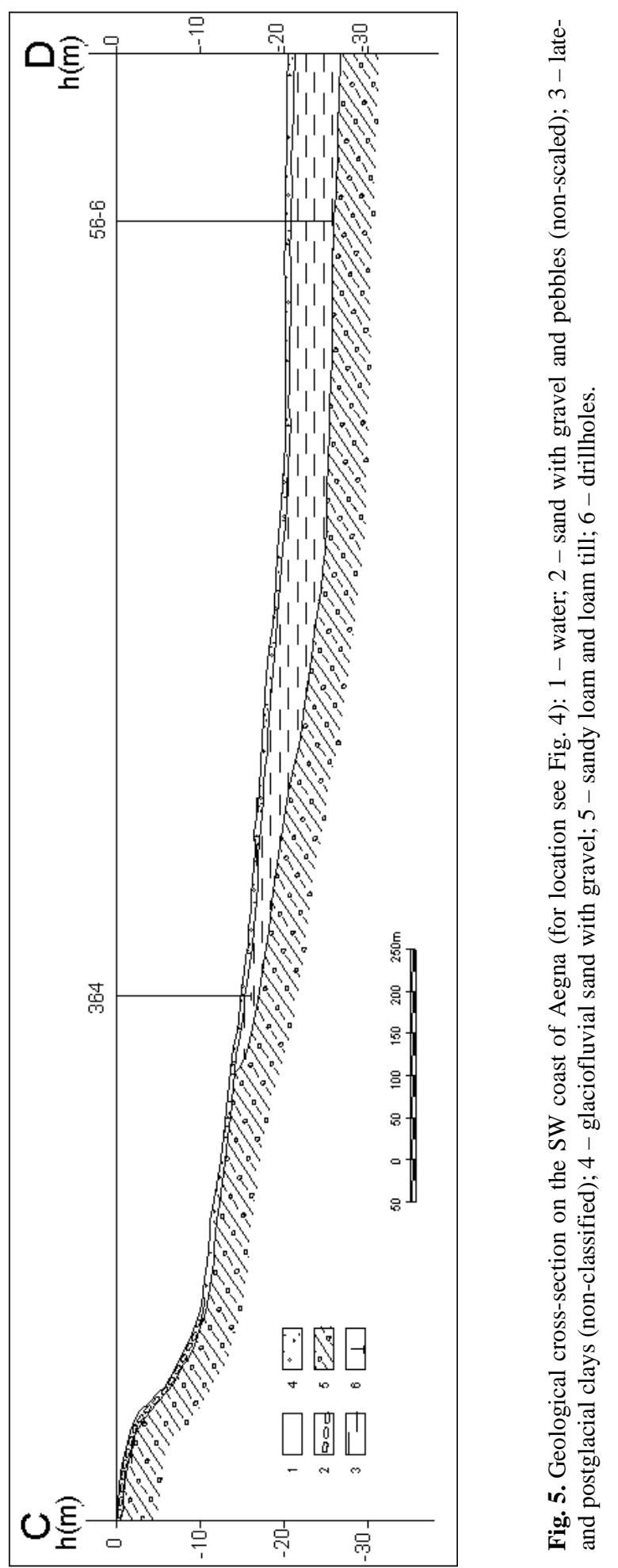


During a severe storm in November 2001, a large amount of sediment material of various grain size was eroded from the shore scarp; the material was distributed in the coastal zone and partly carried to the deeper waters. Within the present study the direction of transport and the amount of sediments were not measured, but underwater observations showed that the waves generated by different ships considerably influenced the sediment transport.

\subsection{Eastern coast of Naissaar}

The eastern shoreline of Naissaar passes from the south to NNW. The shoreline is little dissected, except few eastward extending capes, for example, Hülkari and Virbi (see map on the inside backcover), as well as the harbour where sand has accumulated behind a jetty.

Waves travelling from the ship lane towards Naissaar may cross the Keskmadal, Littegrund, or Naissaar banks. Keskmadal is a seafloor elevation covered with pebbles and cobbles, located at a distance of $7.2 \mathrm{~km}$ from the Pikasääre Cape (minimum water depth is $1.4 \mathrm{~m}$ ). Littegrund (minimum water depth $0.2 \mathrm{~m}$ ) is situated $5.2 \mathrm{~km}$ from the Hülkari Cape. The Naissaar bank is $2.8 \mathrm{~km}$ to NE of the island. Its central part is covered with pebbles and cobbles. The minimum water depth is $1.9 \mathrm{~m}$.

The deposition eastward of Naissaar is influenced by the above-described as well as other shallow areas, serving as sources for sediment material. The seafloor is covered with sand and silt that originate partly from the eastern coast of this island, and partly from the banks consisting of glaciofluvial deposits. The area between the eastern coast of Naissaar and the eastward banks can be treated as a closed system $\left[{ }^{15}\right]$. Large amounts of new sediment material is not deposited here and virtually no suspended matter is emitted from the sediments of the area, because the share of fine material (less than $0.063 \mathrm{~mm}$ ) is small.

The geological setting of the eastern coastal zone is depicted in Figs. 7 and 8. Along the shoreline till is covered with an about $2.5 \mathrm{~m}$ thick layer of marine sand. Between the $4 \mathrm{~m}$ and the $5 \mathrm{~m}$ depth contours the thickness of the sand layer abruptly decreases towards the sea. According to drillholes made on Naissaar and seismoacoustic measurements, Cambrian blue clay occurs $45 \mathrm{~m}$ below the sea level. Approximately $700 \mathrm{~m}$ from the shoreline the bedrock surface rises for $10 \mathrm{~m}$ and the thickness of till and glaciofluvial sand and gravel decreases. Under the thin layer of sand late- and postglacial clays occur. Seismoacoustic sounding profiles made in the area show that SE of the Hülkari Cape there is a valley incised into the till, but the present data do not allow to determine its direction. The valley may possibly strike parallel to the shoreline.

Directly northward of the quay of Naissaar harbour, the sea floor lowers abruptly. The $2 \mathrm{~m}$ depth contour is $30-40 \mathrm{~m}$ from the shoreline. Landward from the shoreline the ground surface rises abruptly (Fig. $9^{*}$ ). 


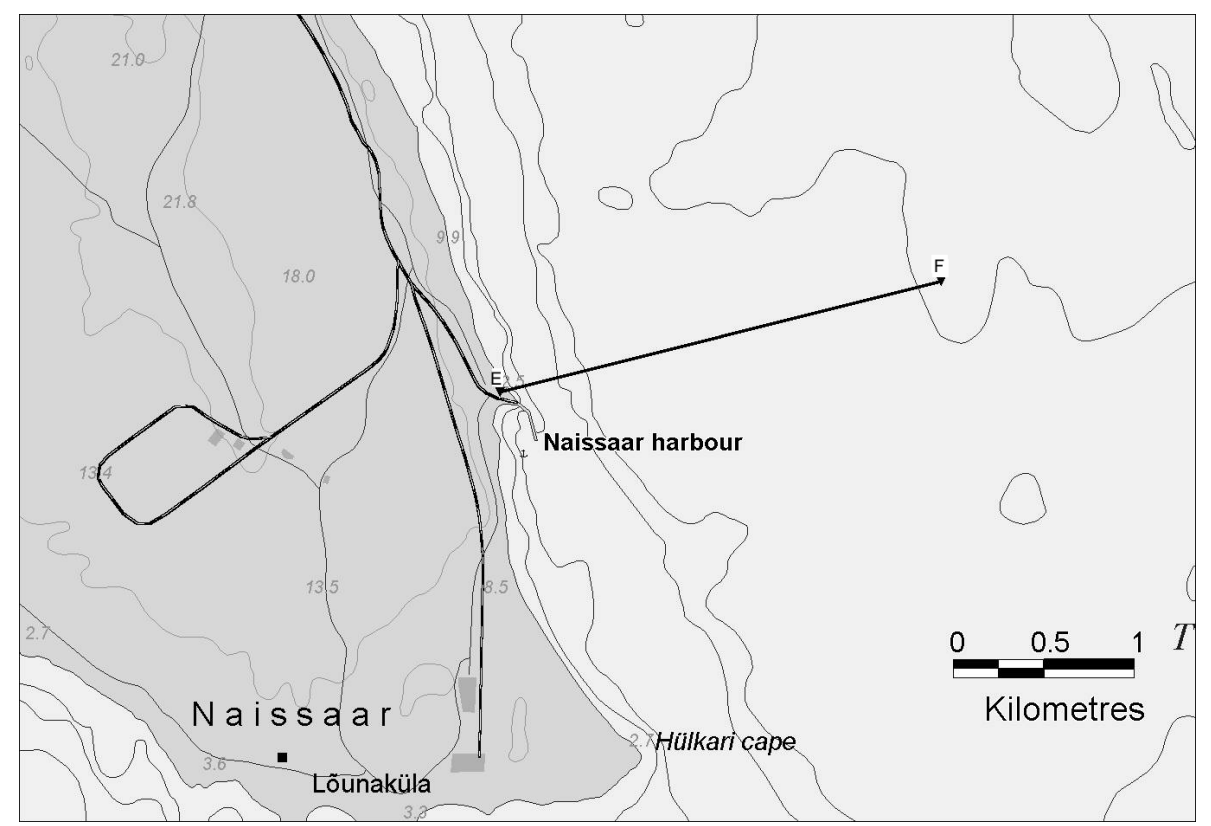

Fig. 7. Location of the geological cross-section on the eastern coast of Naissaar (topographic base the base map of Estonia at the scale of $1: 50$ 000).

Measurements carried out within the present study showed that during the 2001/2002 autumn and winter storms active sediment transport and redistribution took place.

In the surroundings of Naissaar harbour sand is most widely distributed. In the upper part of the shore medium sand dominates. NW of the jetty coarse sand with gravel is distributed as a narrow strip at the shoreline, which refers to intense wave wash. The gravel is well sorted. On the seafloor, closest to the shoreline fine to medium sand occurs, while fine sand dominates in the deeper parts. Distribution of different sand fractions varies depending on hydrodynamic conditions, but the described pattern was observed also in 2002. At water depths greater than $10 \mathrm{~m}$, in some places fine sand alternates with dense silt. Generally pebbles and cobbles are common in the coastal zone of Naissaar, but in the area under observation the latter is covered by sand. By now the accumulated sand has filled the area behind the jetty (Fig. 10*) and therefore the sediment drift is headed further southward. Sand is more influenced by waves and currents and is carried on along the nearshore. In relatively short time sand has filled also the mouth of Naissaar harbour where in the 1980s the water depth was 6-7 m, in the beginning of the $1990 \mathrm{~s}$ only $2 \mathrm{~m}$, and presently $1-1.5 \mathrm{~m}$. This shows that a large amount of sand has been transported to the observed area. 


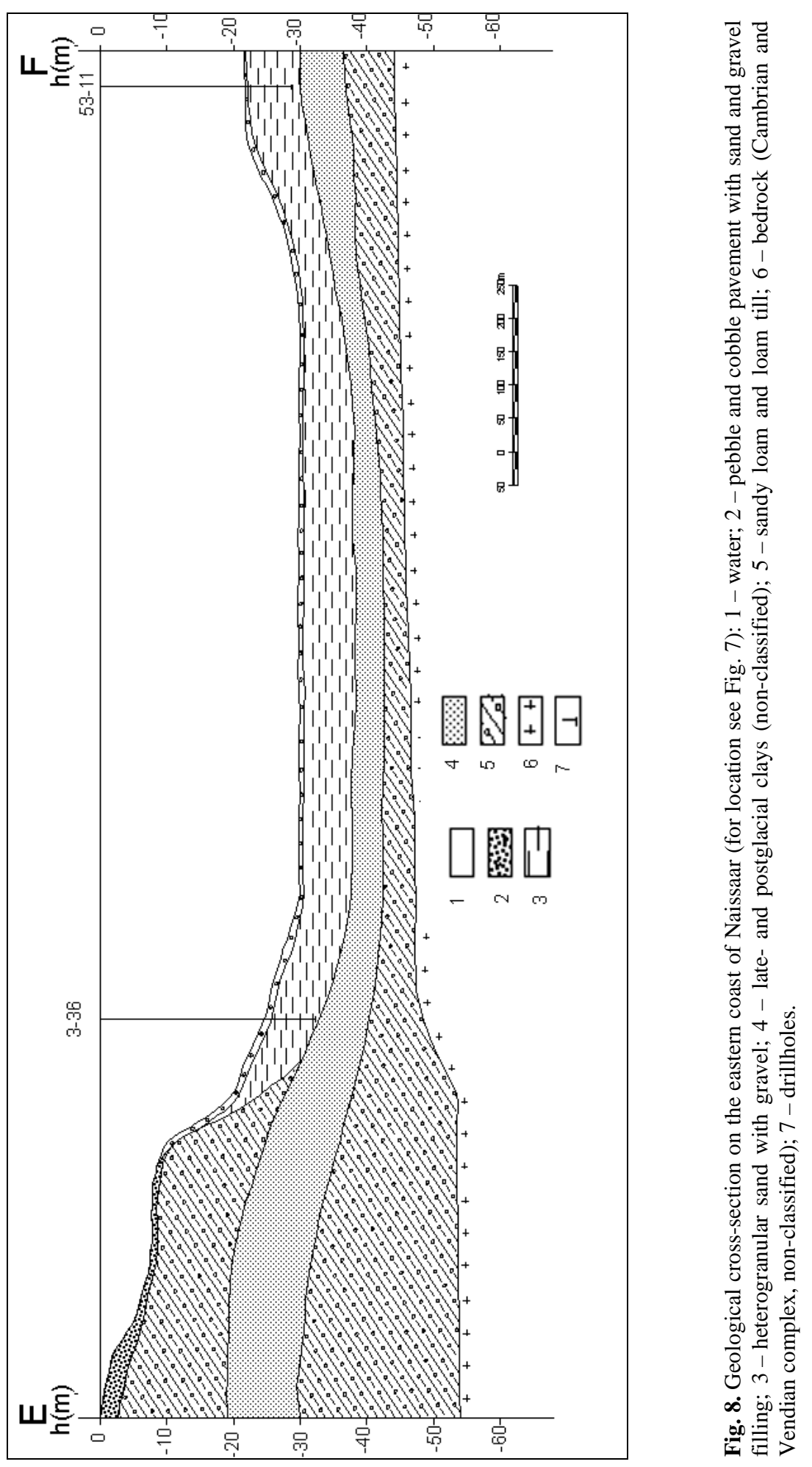




\section{WAVE-INDUCED CHANGES OF SHORES}

The influence of wave activity on shores can be estimated based on erosion and accumulation processes. Around Tallinn Bay most of the shores consist of till. They are often covered with pebble and cobble pavement, which to some extent protects the shore from further erosion.

Among accumulation areas, sandy shores are spread on a limited area. In several places short sections of pebble shores occur, but identification of this type of shore is mostly complicated. Based on geomorphological appearance, scarp shores can be observed in different deposits around Tallinn Bay. Mostly the scarp is 1-2 $\mathrm{m}$ high and is eroded only under conditions of high water level combined with strong wave activity. Such conditions mostly occur during the autumn-winter period. On 15 November 2001 the sea level was extraordinarily high $-1.30 \mathrm{~m}$ above the average level. The previous maxima occured in years 1991 and 1967, when the water level was $1.25 \mathrm{~m}$ and $1.24 \mathrm{~m}$ above the average, respectively. These conditions were accompanied by intense wave activity, which induced erosion of scarp shores normally situated above the water level. The severe storm lasted for a few days and nearly all shores suffered from erosion. As a result, large amounts of sediments were loosened and spread in the coastal zone.

The material eroded on the shore can be transported along the coastal zone during low sea level. Fast ferry traffic occurs frequently during periods when the sea level is low. Thus the waves generated by fast ferries, which have a specific shape and a high energy, influence first of all sediment transport in the coastal zone seawards from the shoreline.

\subsection{Western coast of the Viimsi Peninsula}

The coastal zone (Fig. 3) is built up mainly of till of variable content of coarse-grained material. The till shore begins in Merivälja area where the Pirita ancient valley is connected to the sea (see map on the inside back cover). Abundant pebbles and cobbles occur on the foreshore, with clay, sand, and gravel between them.

The local shore processes are influenced by Merivälja jetty. Northward of it a small amount of sediments was deposited on the shore and during the November storm of 2001 this area widened. Southward of the jetty erosion dominates, but the massive pebble-cobble pavement protects the shore. Between the jetty and Miiduranna area the shore scarp is eroded during the point influence of high water level and intense wave wash. Generally the pebble-cobble pavement reduces the influence of wave activity on the shore. Between Merivälja jetty and Pirita, next to the jetty, the erosion of the shore scarp has diminished and the old erosion scarp is partly grown over with plants. In November 2001 the scarp was again eroded, sediments were loosened from its lower part and certain sections of the upper part fell down. 


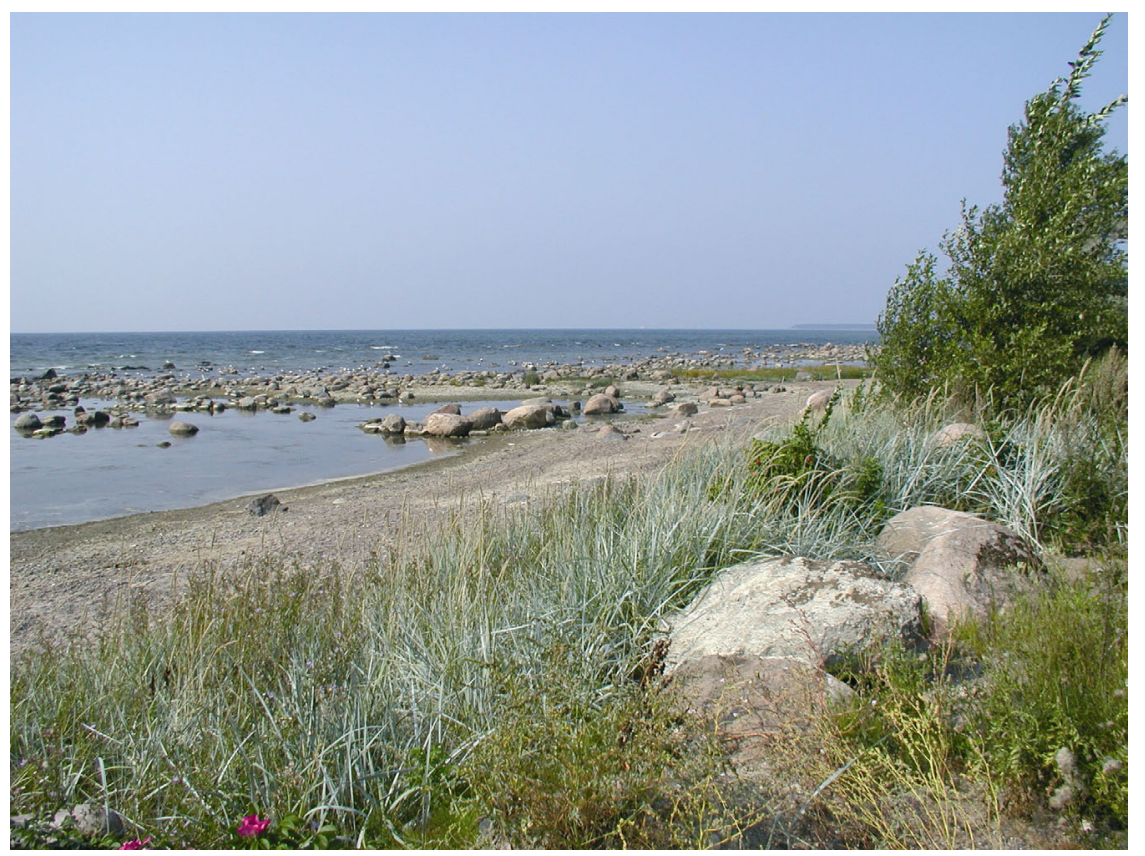

Fig. 1. Western coast of the Viimsi Peninsula. Abundant cobbles and boulders are found in the coastal area. Photo by A. Kask.

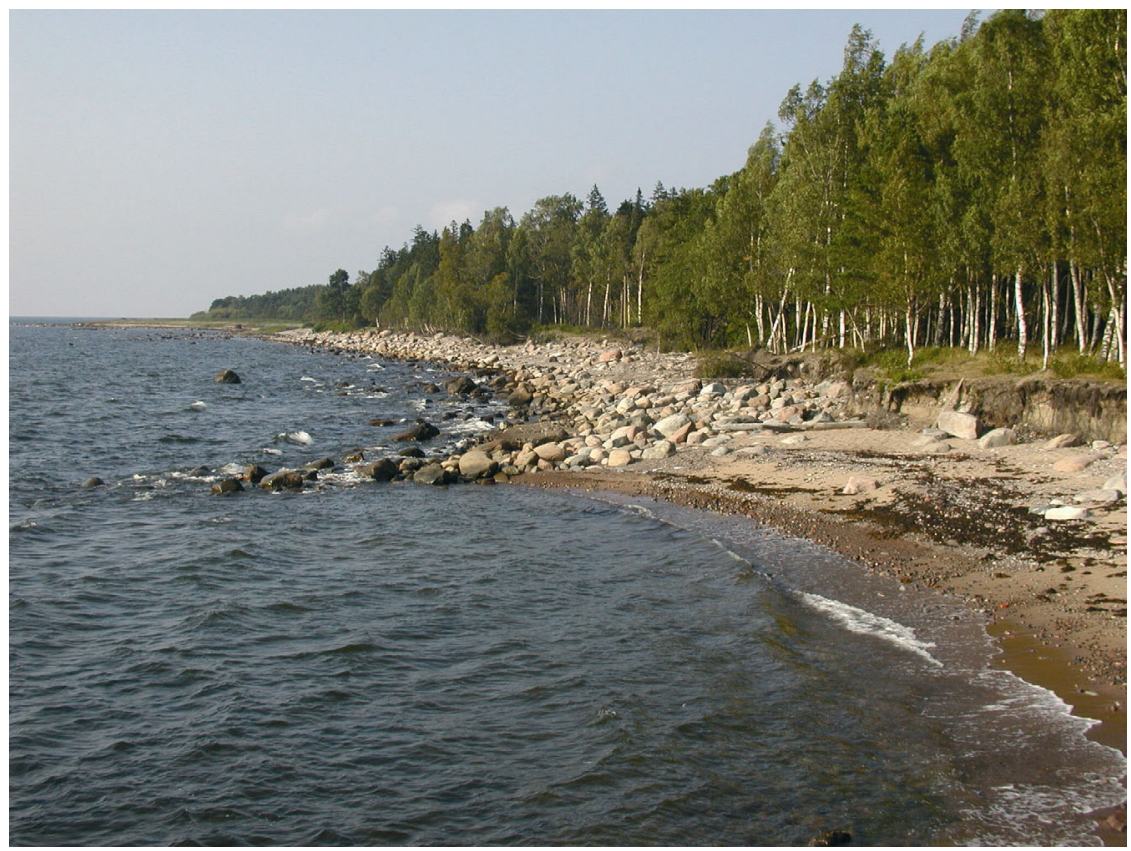

Fig. 6. Southwestern coast of Aegna. Pebble and cobble pavement covers the coastal area. Photo by A. Kask. 


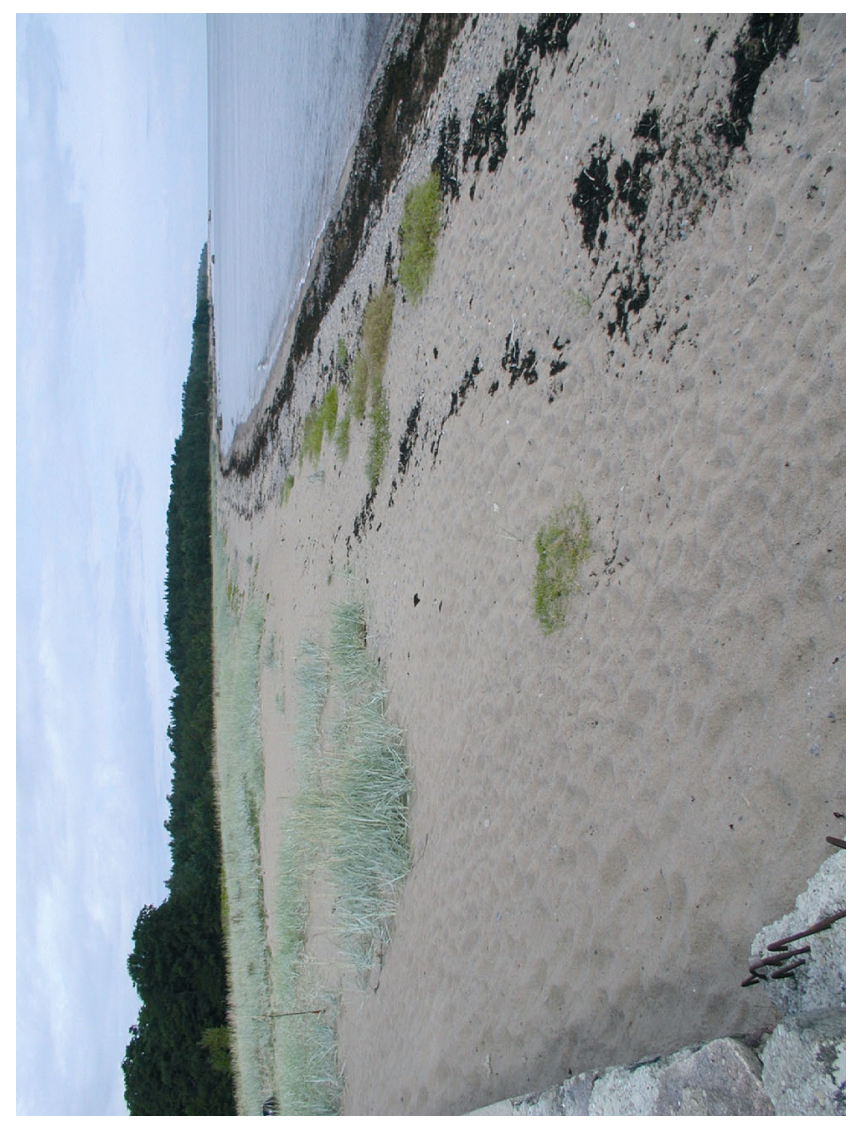

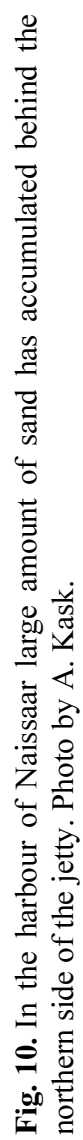
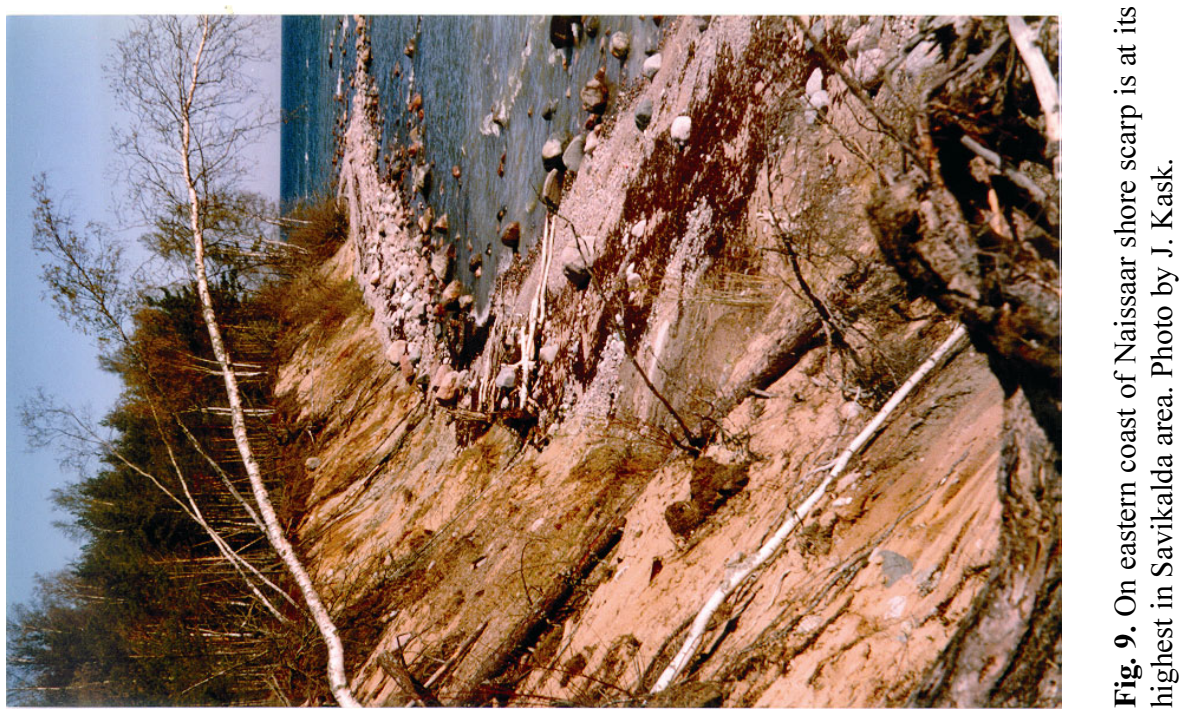
Directly southward of Miiduranna harbour the shore has retreated for a long time. Erosion processes started when Miiduranna harbour was built. The moles have changed the hydrodynamic conditions and now prevent sediment transport in the coastal zone. Presently, on the shore bordering with the Lahe Street, there are some landing places for boats with moles constructed of boulders. Due to the latter, the energy of waves decreases before they reach the shore and the erosion diminishes. Because of the gently sloping foreshore, the influence of waves generated by fast ferries on the shore processes is small.

Northward of Miiduranna harbour, till shore is spread. Plants growing in the upper part of the backshore indicate that the intensity of the shore processes is low.

Between Miiduranna and Pringi, southward of the Pringi Cape, there is a shallow bay with a sandy backshore and abundant pebbles and cobbles. In the landward part of the shore, foredunes covered with plants occur. Abundant pebbles and boulders with sand and gravel between them are found on the foreshore. The nearshore is wide and gently sloping, therefore high waves break before they reach the shoreline. The sandy shore continues up to the Pringi Cape. In this area the autumn and winter storms have not much influenced shore processes. A presently flattening and vegetated scarp on the southern coast of the Pringi Cape gives evidence of former intense erosion.

Northward of Pringi harbour, the shore is more exposed and subject to (more) intense wave activity. Close to harbour considerable changes have occurred and the scarp has retreated for about $1 \mathrm{~m}$.

On the shore in front of the Viimsi Museum, abundant pebbles and cobbles with coarse gravel between them are found on the shore. The till shore is mostly covered with a pebble-cobble pavement. In this shore section both erosion and accumulation take place. The shore scarp is eroded in ancient beach ridges. The till shore is spread also northward of the museum. There are also some landing places for boats with short moles built up of single big boulders. The pebblecobble pavement protects the coastal zone from further erosion. The nearshore is gently dipping and waves break far away from the shoreline. As compared with 2001, the appearance of the shore has changed only a little.

The till shore spreads in the NE direction and northward up to the end of the Viimsi Peninsula. The Cambrian blue clay forms the basement of the till. In several places on the shore, there occur beach ridges made of sediment material of variable grain size, from fine sand to boulders. Pebbles, cobbles, and boulders occur almost everywhere on the shore and nearshore and protect them from further erosion. Sediment accumulation occurs only locally in some coves. In some places gravel is found between the pebbles and cobbles both on the shore and in the nearshore.

During the two-year observation period, several harbours were built or reconstructed on the western coast of the Viimsi Peninsula. They change the hydrodynamic processes in the coastal zone, but apparently their influence on the geological setting of the coastal zone made of terrigenous deposits is small. 


\subsection{Southwestern coast of Aegna}

Eastward of Aegna harbour (Fig. 4), there is scarp shore, with the height of 2-3 $\mathrm{m}$. The part of the scrap, bordering with the harbour, is flattened and vegetated, and is from time to time eroded by high water stand and heavy waves. Pebbles and cobbles occur on the shore and in the nearshore.

A sandy shore is spread between the harbour and the Kalavälja Cape (a small cape between the harbour and the Talneem Cape). The thickness of the sand layer is relatively small and pebbles and cobbles are found on the foreshore. In this shore section accumulation takes place, which can be clearly seen near the harbour mole. At the shoreline, small capes made of gravel and pebbles occur. As compared with 2001, this area has somewhat widened.

Westward of the Kalavälja Cape a till shore is spread, reaching the Talneem Cape. The whole shore section is vegetated, which indicates a low intensity of shore processes. A vegetated scarp is situated landward of the shoreline, giving evidence of former intense erosion. This scarp extends also to the previously described sandy shore. The till shore is covered with abundant pebbles and cobbles with few boulders. During the autumn-winter period of 2001/2002, under conditions of high water stand, the wave activity has influenced areas far beyond the average shoreline.

Major changes were observed on the shore in the area of the Talneem Cape, where the scarp is $2-3 \mathrm{~m}$ high. In this area a stone jetty, built for the searchlight of a former coast defence unit, was situated. Now it has been destroyed by ice and waves.

Shore processes are active on a 500-600 m long section northward of the Talneem Cape, where traces of erosion are observed in the shore scarp. The coastal zone is mostly made of pebbles and cobbles, coarse sand and gravel occur sporadically. This finer material is relocated by waves or transported to deeper areas. The pavement is underlain by till, which is spread also further on the seafloor, but is covered by sand. This till shore has been subject to erosion for a long time already. In this area the nearshore is steeper and therefore waves' energy is high when they reach the shore, thus causing considerable changes during the high water stand. During our observations also the waves generated by fast ferries forced the sediments into movement and caused sediment transport in the coastal zone.

About $100 \mathrm{~m}$ northward of the Talneem Cape concrete blocks are found at the shoreline. It is not known whether it was a coastal protection wall or some other building, but obviously erosion processes have been active here for a long time already. Although the shore is protected by the pavement, the 1-2 m high scarp is eroded during high water stand and by heavy waves (like on 15 November 2001). Coarse material (pebbles, cobbles) remains on the shore, while sand and finer sediments are transported along the shore to areas of deposition. In 2001 we installed some pickets landward of the shore scarp. During the autumn-winter period of 2001/2002 the retreat of the scarp was the smallest in its SE part 
(1-2 m), while in the NW part the retreat was approximately 2-3 m (maximum $4 \mathrm{~m}$ ). The retreat was the biggest in the areas where a pipeline was exposed in the scarp. As these changes took place during the highest water level of the century, it is assumed that normally the scarp withdraws less intensely.

Northward of the described shore section there is a wide accumulation shore, built up of sand and gravel with partly vegetated foredunes. Here the coastal zone is wide and gently sloping, with abundant pebbles and cobbles. Therefore usually waves do not change this shore section and the active development of the shore has stopped. High water stand together with heavy waves may cause only minor changes.

In summer 2002 no considerable changes were observed on the SW coast of Aegna. Waves moved away only fine sediments (sand and gravel) that had accumulated between pebbles and cobbles during winter storms.

\subsection{Eastern coast of Naissaar}

The shoreline of Naissaar (Fig. 7) is more than $20 \mathrm{~km}$ long. The eastern coast of the island is higher than the western one and in places scarps occur. Normally the forest extends to the upper border of the shore, except in its southern and northern parts.

In the NE part of the island, near the Virbi Cape, abundant cobbles and pebbles are found in several places on the shore as well as in the nearshore. Such shore, built up of variable coarse-grained material, is spread southward, to the Jurka and Savikalda area. A severe storm in November 2001 caused considerable changes and a scarp was eroded into the formerly flat shore.

On the NE coast of Naissaar, near Savikalda, a more than $9 \mathrm{~m}$ high scarp has been eroded in the till and marine sands. The backshore in front of the scarp is relatively narrow $(5-6 \mathrm{~m})$. The foreshore is made of pebbles and in some places of cobbles, sand and gravel are less common. The nearshore is gently sloping. The upper part of the shore scarp consists of $3 \mathrm{~m}$ thick medium sands that overlie till. The permeability of sand is high and therefore surface and groundwater flow out at the boundary between the sand and the underlying till, thus causing landslides in the scarp. This is a typical erosion shore from where pelite and silt are carried to the deeper waters while sand is transported along the nearshore.

Within the coastal monitoring programme we have monitored the development of the Savikalda shore scarp for the last five years. The changes have occurred mainly in spring when landslides occur as a result of winter storms, snowmelt water, and groundwater. During the autumn-winter period of 2001/2002 the withdrawal of the Savikalda scarp continued. In summer the changes are small.

Southward of the Savikalda scarp there is a long shore section covered with material of variable grain size. In places between the pebbles and cobbles, gravel and sand of different grain size are found. There are short sections (for example, around Lehtmetsa) where sand dominates shore deposits (landward of these sections ancient beach ridges with dunes are found). The nearshore is covered 
with pebbles and cobbles, under which till occurs. The shore is gently sloping. In the landward part of the backshore, scarps in loose deposits are often found, indicating the influence of storm waves. Thus it can be concluded that the shore is variable and heavy waves may considerably change its appearance.

One of the most extensive sandy shores on the eastern coast of Naissaar is situated directly northward of the harbour. It begins south of the Sinkarka reef (see map on the inside back cover) and reaches the harbour mole. This shore of accumulation consists of sand and gravel and has formed due to the existence of the harbour. Landward of the present shoreline there are ancient coastal beach ridges partly overgrown with plants. These ridges are built up mainly of fine to medium sand. Presently medium sand is found at the shoreline, coarse gravel occurs in the section closest to the harbour. The gravel is well sorted, which indicates intense hydrodynamic activity in this zone. Sand is carried from the north towards the south, passing the harbour, because the area behind the jetty is already filled with sand. The natural waves are an important agent of sediment transport, but changes in water turbidity when the ship wake reaches the shore $\left[^{7}\right]$ show that the waves generated by fast ferries are also able to carry sediments on the nearshore.

Southward of the harbour, a typical scarp shore is observed. Its upper part is made of marine sands and the lower part consists of till. The 2-3 m high scarp is active; sand forms about $2 \mathrm{~m}$ of its total height. In 2001, in some places there was a talus slope made of till and sand in front of the scarp, but it was carried away during the autumn-winter storms of 2001/2002. Like in the Savikalda scarp, there occur surface- and groundwater outflows at the upper surface of till. The shore is narrow, with few boulders and cobbles; it consists of sand, gravel, and pebbles. Abundant pebbles and cobbles are found in the coastal zone. The sand washed out of till is carried southward, towards the Hülkari Cape. In the southern part of the island the scarp is replaced by a sandy shore; till probably lies deeper and is covered with sand.

Northwards of the Hülkari Cape a sandy shore with some gravel is spread. The storm of 15 November 2001 together with high water stand caused considerable changes in this area. The landward boundary of the backshore was previously low and flat, but by spring of 2002 it had become much higher, with a steep seaward side. This indicates that a large amount of sand has been carried away from this area.

On the eastern coast of Naissaar, erosion or sediment transport takes place on the nearshore, but at 10-20 m water depth the seafloor is covered with silt, which covers till. In a depth of $30 \mathrm{~m}$ a sediment complex of an earlier Baltic Sea stages or glaciolacustrine deposits are exposed on the sea floor.

\section{CONCLUSIONS}

Analysis of the geological setting and shore processes in Tallinn Bay area shows that generally ship waves do not cause direct erosion of the shores. In the 
areas observed, till shore dominates. Generally these deposits are covered with a pebble and cobble pavement, which protects the shore from further erosion; thus the ferry-generated waves are not able to erode these shores considerably. The described changes in the shores (in the upper part of backshore during the observation period, including autumn-winter 2001/2002) were mostly due to the storms. Thus in the vicinity of the shoreline the waves, generated by fast ferries, play a rather insignificant role. In certain coastal areas of Tallinn Bay local longshore currents during the high navigation season are predominantly oppositely directed as compared to those prevailing during strong autumn and winter storms [ $\left.{ }^{7}\right]$. Therefore the total intensity of transport of fine sediments towards the bayhead (Pirita-Maarjamäe area) can be even somewhat reduced.

The period of ship-generated waves frequently is much longer than that of wind waves. They induce near the bottom of deeper nearshore (5-20 m) water movement at rates that are rarely generated by wind waves $\left[{ }^{16}\right]$. Therefore the waves of different origin probably transport sediment material at different water depths. This is indirectly confirmed by the considerably reduced transparency of sea water in the result of waves of fast ferries $\left[{ }^{7}\right]$.

\section{ACKNOWLEDGEMENTS}

Authors are grateful to Indrek Kask, Sten Suuroja, Martin Suuroja, Külli Tenson, and Ivar Tenson for their assistance during the field work period. Thanks are due to Tarmo Kõuts for discussion on the sediment transport problem. This study was mostly performed in the framework of the project "The influence of ship wakes on beaches of the Viimsi Peninsula and Naissaar and Aegna islands, and the possibilities of its neutralizing", financed by the Estonian Environmental Investment Centre.

\section{REFERENCES}

1. Komar, P. D. Beach Processes and Sedimentation. 2nd ed. Prentice Hall, Upper Saddle River, 1998.

2. Soomere, T. and Rannat, K. An experimental study of wind waves and ship wakes in Tallinn Bay. Proc. Estonian Acad. Sci. Eng., 2003, 9, 157-184.

3. Schwarzer, K., Diesing, M., Larson, M., Niedermeyer, R.-O., Schumacher, W., and Furmanczyk, K. Coastline evolution at different time scales - examples from the Pomeranian Bight, southern Baltic Sea. Marine Geol., 2003, 194, 79-101.

4. Hannon, M. A. and Varyani, K. S. The wash effect of high speed ferries in coastal and inland waterways. In Proc. International Conference on Coastal Ships and Inland Waterways, RINA. London, 1999 (CD).

5. Kirkegaard, J., Kofoed-Hansen, H., and Elfrink, B. Wake wash of high-speed craft in coastal areas. In Coastal Engineering 1998. Proc. 26th International Conference. Copenhagen, 1998, (Edge, B. L., ed.). American Society of Civil Engineers, 1999, vol. 1, 325-337.

6. Forsman, B. From bow to beach. SSPA Highlights, 2001, No. 3, 4-5. 
7. Soomere, T., Elken, J., Kask, J., Keevallik, S., Kõuts, T., Metsaveer, J., and Peterson, P. Laevaliikluse purustav mõju Viimsi poolsaare, Aegna ja Naissaare randadele ning selle neutraliseerimise võimalused. Res. Report. Marine Systems Institute, Tallinn, 2002.

8. Talpas, A., Kask, J., Mardla, A., Väling, P., and Sakson, M. Balti mere šelfiala geoloogiline kaardistamine mõotkavas 1:200 000. Map sheets 0-34-VI, 0-34-XII, 0-35-I, II. Res. Report. Geological Survey of Estonia, Tallinn, 1994.

9. Soulsby, R. Dynamics of Marine Sands. A Manual for Practical Applications. Thomas Telford Publications, London, 1997.

10. Rumohr, J., Walger, E., and Zeitschel, B. (eds.). Seawater-sediment Interactions - An Interdisciplinary Approach. Lecture Notes on Coastal and Estuarine Studies, No. 13. Springer, Berlin, 1987.

11. Coastal Engineering Manual. Department of the Army. U.S. Army Corps of Engineers. Manual No. 1110-2-1100, Washington, D. C., 2002.

12. Peltoniemi, H., Bengston, A., Rytkönen, J., and Kõuts, T. Measurements of fast ferry waves in Helsinki-Tallinn route. In Abstracts, Symposium "The changing state of the Gulf of Finland Ecosystem". Tallinn, 2002, 32.

13. Soomere, T. and Kask, J. A specific impact of waves of fast ferries on sediment transport processes in Tallinn Bay. Proc. Estonian Acad. Sci. Biol. Ecol., 2003, 52, 319-331.

14. Soomere, T. and Keevallik, S. Directional and extreme wind properties in the Gulf of Finland. Proc. Estonian Acad. Sci. Eng., 2003, 9, 73-90.

15. Lutt, J. and Tammik, P. Bottom sediments of Tallinn Bay. Proc. Estonian Acad. Sci. Geol., 1992, 41, 81-87.

16. Soomere, T., Rannat, K., Elken, J., and Myrberg, K. Natural and anthropogenic wave forcing in the Tallinn Bay, Baltic Sea. In Coastal Engineering VI (Brebbia, C. A., Almorza, D., and Lopez-Aguayo. F., eds.). WIT Press, Southampton, Boston, 2003, 273-282.

\title{
Kiirlaevade poolt ohustatud piirkondade geoloogiline ehitus Tallinna lahes
}

\author{
Jüri Kask, Aado Talpas, Andres Kask ja Klaus Schwarzer
}

On vaadeldud Tallinna lahe põhjasetete jaotust sõltuvalt üldisest geoloogilisest ehitusest. Detailsemalt on käsitletud rannavööndi osi, mida kiirlaevade liikumisest tekitatud lainetus võib rohkem mõjutada (Viimsi poolsaare läänerannik, Aegna saare edelarannik, Naissaare idarannik). Põhjasetete jaotus Tallinna lahes on seotud kulutusalade paiknemise ja sügavussuhetega. Rannavööndis on valdav liustikusetetest väljapestud jämedateraline purdmaterjal, mis vähendab lainetuse mõju selles piirkonnas. Paguveega esinev kiirlaevade lainetus mõjutab piirkonda, mis jääb rannavööndi sügavamasse ossa. 